DOI: doi.org/10.21009/IJLECR.062.16

Received: 10 May 2020

Revised: 6 June 2020

Accepted: 5 November 2020

Published: 1 December 2020

\title{
EXPLORING DIGITAL ETHNOGRAPHY APPLIED TO LANGUAGE LEARNING STUDY: A LITERATURE REVIEW
}

\author{
Rina Husnaini Febriyanti ${ }^{1, a)}$, Ninuk Lustyantie ${ }^{2, b)}$

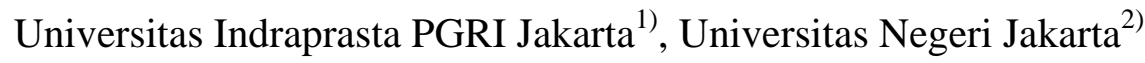 \\ rina.husnaini@unindra.ac.id ${ }^{\text {a) }}$, Ninuk.lustyantie@unj.ac.id ${ }^{\text {b) }}$
}

\begin{abstract}
Digital or virtual atmosphere in education field today begins spready that includes in area of language learning. In line with that one, research design is proposed in the similar context that is Digital Ethnography (DE). This research aims are to reveal and explore the detail of DE and how it is implemented in research. The method used in this study is qualitative, and the data is collected from 10 articles from reputable journals that discuss about DE. The collection data were categorized based on the year, title, author, purpose, method result and discussion, and conclusion, afterwards they were analysed and presented descriptively. The findings of this study showed that DE can be applied in various topic particularly in language learning research. The implication of this study DE can be as the one of the options as the research design related to language learning in digital or virtual context.
\end{abstract}

Keywords: Digital Ethnography, Language Learning, Literature Review

Digital media in daily life recently increase in many fields that include in research field. Those digital media are such as internet, website, blog, vlog, video, platforms that even also mobile media that can be as the aids in the learning and teaching process (Muranova, 2016). Through it many researchers observe and dig about them as the main field of research topic as phenomenal issue today. In line with the era of industry revolution of 4.0 that the era of digitalization where all thing is in our hand easily, this happens to education and research field whether it is done in online or offline. In addition, the activities of language learning and teaching process may be held whether inside or outside the classroom. The several researches that investigated some technology aids in language learning for instance applied on practicing technology tools such as video materials (Bajrami \& Ismaili, 2016), technology integration planning cycle (Beschorner et al., 2018), platform of Skype and Zoom (Cuaca Dharma et al., 2017), technology-supported LEA (Jozwik \& Mustian, 2019), digital storytelling (Tridinanti, 2017), and social networking of Facebook (Sirivedin et al., 2018). There are also on technology concern in development researches particularly on designing Information, Communication and Technology such as designing ICT competences-integrated language awareness (English phonetics and phonology, English morphology and syntax, and English socio-pragmatic) (Tampubolon \& Darmahusni, 2019), designing ICT competences - integrated writing syllabuses (Syifa \& Darmahusni, 2019), designing ICT competence- integrated syllabuses of reading course (Bandan \& Dewanti, 2019), and designing ICT competences-integrated syllabuses of Grammar courses (Purnawati \& Iskandar, 2019). In the same time, the forward progressing of technologies applied in teaching and learning activities 
influence the way or the method used in research field. For instance, as the previous mentioned that the research may be done in offline or online as included in ethnography research method that emergently transforms from traditional ethnography to digital ethnography research method.

Digital ethnography is a method that emerges from ethnography method, yet the atmosphere is closely different that is the space not similar where ethnography traditionally portrays in offline way, while digital ethnography (DE) is in online or virtual way. Based on glancing theoretically, it is not different such both defines as literally writing about groups of people. Historically, ethnography was developed from cultural anthropology by an emphasis on the issues of writing about culture then it spread to sociology and education. The ethnography design in qualitative research procedures for describing, analysing, and interpreting a culture-sharing group's shared patterns of behaviour, beliefs, and language that develop over time. The essence of this definition is culture that includes language, rituals, economic and political structures, life stages, interactions, and communication styles. To understand the patterns of a culture sharing group, the ethnographer typically spends considerable time "in the field" interviewing, observing, and gathering documents about the group to understand their culture-sharing behaviours, beliefs, and language (Creswell, 2012).

Ethnography refers to writing about culture. Field research takes place in natural settings, referred to as the field. This approach to research relies on the researcher engaging in direct observations of people in their natural settings in order to understand social life from the perspective of the participants Ethnographers aim to describe the culture in which the research participants are enmeshed. This approach to research result in "thick descriptions" of social life (Leavy, 2017). In other terms, ethnomethodology refers not to research methods but rather to the subject matter of study: how (the methodology by which) people maintain a sense of an external reality. This method is to examine the ways people apply abstract cultural rules and common-sense understandings in concrete situations to make actions appear routine, explicable, and unambiguous. Meanings, the practical accomplishments on the part of members of society (J. Taylor et al., 2016).

On the other hand, not go so far with ethnography, it is digital ethnography (DE) that outlines an approach to doing ethnography in a contemporary world. It invites researchers to consider how we live and research in a digital, material and sensory environment. Digital Ethnography also explores the consequences of the presence of digital media in shaping the techniques and processes through which we practice ethnography and accounts for how the digital, methodological, practical and theoretical dimensions of ethnographic research are increasingly intertwined (Pink, 2016). Whereas, DE is such kind a of a research design that provide spaces for speculation and for creative, even playful explorations of ethnography as a series of changing approaches, theories, and probes (Hjorth, 2017). These interdisciplinary conversations are critical for the vibrancy of digital ethnography as a field and practice. In the similar line, digital visual research technologies accompany researchers, participants in research and audiences of the outcomes of research through everyday digital material worlds and to inhabit this world in particular embodied and affective ways that move through the digital materiality (Horst, 2017).

Otherwise, the steps in DE as follows: 1) hidden observation, individuals in the community are observed and the researcher does not actively involved in the relationship dynamics of the network, 2) detecting the presence of content involved, 3) crawling content: with crawling means a computer process by which you can download the contents of a computer database, 4) reconstruction of the relationship network, 5) analysis of "the traces of growth" ,6) Classification and ideal types. Therefore, those steps are supposed to be implemented in DE (Russo, 2017).

In addition, the term of combination between ethnography in blended environment with technology from 'cultural' to 'ecological' in order to combine the behaviour of both human technologies and machine technologies described as in the following chart: 


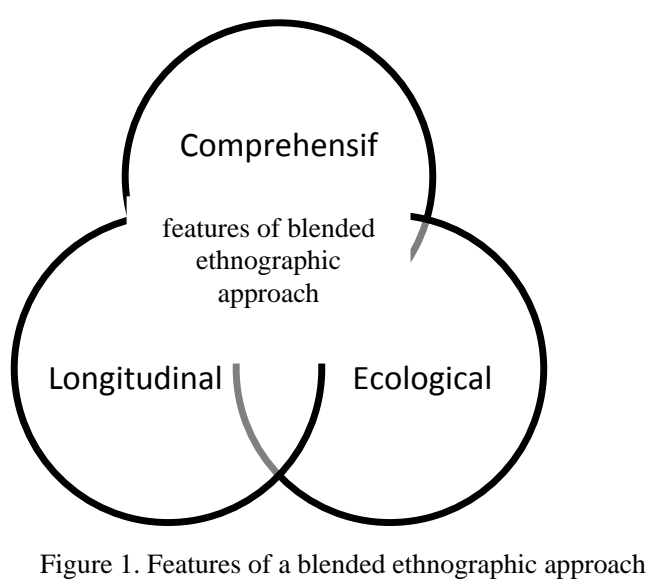

The three major types of ethnography for blended environments, based on meso, macro, or micro analysis they are as follows : (1) classroom ethnography, (2) institutional ethnography, and (3) autoethnography where a classroom ethnography investigates the use of technologies in action as teachers employ processes to achieve language learning tasks. Meanwhile, ethnography of an institution looks at the culture of the whole program and in institutional such as the case of a university, a four-year learning process of a student in their foreign language studies. Lastly, an autoethnography is a self-reflective examination of the teaching practice and the personal educational history of the ethnographer. Ethnography and action research are valuable approaches for documenting and interpreting blended environments, which feature multiple, inseparable variables that yield rich insights into how teachers, students, and schools go about blending technologies in a learning ecology (Hinkelman, 2018).

\section{METHOD}

Research method used in this study was qualitative method mainly in literature review about digital ethnography applied in language learning. Qualitative research is the collection, analysis, and interpretation of comprehensive narrative and visual (i.e., nonnumerical) data to gain insights into a particular phenomenon of interest (L.R. Gay, 2012). A literature review is a written summary of journal articles, books, and other documents that describes the past and current state of information on the topic of research study and organizes the literature into subtopics, and documents the need for a proposed study. In the most rigorous form of research, educators base the review mainly on research reported in journal articles (Creswell, 2012).

The data was collected by 10 articles taken from reputable journals that the topic was focused on DE and reduced if the topic was irrelevance. The article sources were taken from such as Eric, Routledge, Springer, ResearchGate link afterwards they were categorized and tabulated based on the articles criteria such as title, author, the aim of the study, method, result and discussion, and conclusion. After those steps, the data were analysed descriptively to find out how the DE was implemented in the studies as the topic discussion or applied research method to explore more and deep understanding on DE. Then, the studies were compared to one to others to get information detail on DE.

\section{RESULTS AND DISCUSSION}

DE is commonly used in many interdisciplinary studies such as were done in sport field about FIA world rally championship fan forums (Næss, 2017), in health field about reproductive health and decision making around pharmaceuticals for patients with inflammatory bowel disease (IBD): investigation of patient attitudes, emotions, and beliefs (Mosadeghi et al., 2016), about ethical considerations and challenges for using digital ethnography to research vulnerable 
populations (Thompson et al., 2020), about online gaming communities (Flyte, 2015). However, in this study only focuses on language learning exploration whether using DE as the topic discussion or research method used. The articles are explored based on DE as follows:

\begin{tabular}{|c|c|c|c|c|}
\hline No & Year & Title & Author (s) & The Aim of The Study \\
\hline \multirow[t]{3}{*}{1} & \multirow[t]{3}{*}{2019} & Bronies Learning & \multirow{3}{*}{$\begin{array}{l}\text { Liudmila } \\
\text { Shafirova } \\
\text { and Daniel } \\
\text { Cassany, }\end{array}$} & \multirow{3}{*}{$\begin{array}{l}\text { To report on fan practices, in English, } \\
\text { among an international community of } \\
\text { bronies adult fans of the animated } \\
\text { cartoon My Little Pony: Friendship is } \\
\text { Magic (MLP)using digital ethnography } \\
\text { (Shafirova \& Cassany, 2019) }\end{array}$} \\
\hline & & English in The & & \\
\hline & & Digital Wild & & \\
\hline \multirow[t]{5}{*}{2} & \multirow[t]{5}{*}{2019} & Project-Based & Maria & \multirow{5}{*}{$\begin{array}{l}\text { To investigate what kinds of } \\
\text { technology used as collaborative aid in } \\
\text { EFL classroom in Japan by using } \\
\text { digital ethnography (Moreira, 2019) }\end{array}$} \\
\hline & & Language Learning & Alfredo & \\
\hline & & with Technology: & Moreira & \\
\hline & & Collaboration in An & & \\
\hline & & $\begin{array}{l}\text { EFL Classroom in } \\
\text { Japan }\end{array}$ & & \\
\hline \multirow[t]{7}{*}{3} & \multirow[t]{7}{*}{2017} & Interactivity and & Emanuela & \multirow{7}{*}{$\begin{array}{l}\text { To know interactive audiobooks as a } \\
\text { way to support individual needs in } \\
\text { relation to exploring different contexts } \\
\text { for reading, freeing interactivity with } \\
\text { audiobooks, and supporting different } \\
\text { modes in relation to the theory of } \\
\text { difference intelligences as well as } \\
\text { challenges in learning foreign } \\
\text { languages or in reading in general. } \\
\text { (Marchetti \& Valente, 2018) }\end{array}$} \\
\hline & & Multimodality in & Marchetti1 & \\
\hline & & Language & and Andrea & \\
\hline & & Learning: $\quad$ The & Valente & \\
\hline & & $\begin{array}{l}\text { Untapped Potential } \\
\text { of Audiobooks }\end{array}$ & & \\
\hline & & & & \\
\hline & & & & \\
\hline \multirow[t]{5}{*}{4} & \multirow[t]{5}{*}{2019} & Teaching & Marion & \multirow{5}{*}{$\begin{array}{l}\text { To investigate an innovative pedagogic } \\
\text { project carried out at the University of } \\
\text { Southampton, in which students were } \\
\text { provided with training in ethnographic } \\
\text { methods and digital skills. (Demossier } \\
\text { et al., 2019) }\end{array}$} \\
\hline & & Ethnography as & Demossier, & \\
\hline & & Modern Languages & & \\
\hline & & $\begin{array}{lr}\text { Method: } & \text { Legacies } \\
\text { and } & \text { Future }\end{array}$ & $\begin{array}{l}\text { Bernasek, } \\
\text { and Heidi }\end{array}$ & \\
\hline & & $\begin{array}{l}\text { Practices for Global } \\
\text { Citizens }\end{array}$ & Armbruster & \\
\hline \multirow[t]{5}{*}{5} & \multirow[t]{5}{*}{2016} & Poetry Writing 2.0: & landoyo & \multirow{5}{*}{$\begin{array}{l}\text { To examine the extent to which Poetry } \\
\text { Writing } 2.0 \text { can create an expressive } \\
\text { and creative English language learning } \\
\text { environment that was drawing on } \\
\text { ethnographic online. (Widodo et al., } \\
\text { 2016) }\end{array}$} \\
\hline & & $\begin{array}{l}\text { Learning to Write } \\
\text { Creatively in }\end{array}$ & $\begin{array}{l}\text { Puji Widodo, } \\
\text { et al }\end{array}$ & \\
\hline & & Blended Language & & \\
\hline & & Learning & & \\
\hline & & Environment & & \\
\hline \multirow[t]{4}{*}{6} & \multirow[t]{4}{*}{2015} & Language Views on & José & \multirow{4}{*}{$\begin{array}{l}\text { To examine the website and data } \\
\text { collected through auto-ethnographic } \\
\text { accounts of the researcher who } \\
\text { participated as a member of the Busuu } \\
\text { community (Álvarez Valencia, 2016) }\end{array}$} \\
\hline & & Social Networking & Aldemar & \\
\hline & & Sites for Language & Álvarez & \\
\hline & & $\begin{array}{l}\text { Learning: The Case } \\
\text { of Busuu }\end{array}$ & Valencia & \\
\hline \multirow[t]{2}{*}{7} & \multirow[t]{2}{*}{2019} & Language Learning & Signe & \multirow{2}{*}{$\begin{array}{l}\text { To investigate the uptake of } \\
\text { affordances for language learning by } \\
\text { young (ages 7-11) Danish children ( }\end{array}$} \\
\hline & & $\begin{array}{l}\text { in The Wild: A } \\
\text { Young }\end{array}$ & $\begin{array}{l}\text { Hannibal } \\
\text { Jensen }\end{array}$ & \\
\hline
\end{tabular}




\begin{tabular}{|c|c|c|c|c|}
\hline & & Perspective & & $\begin{array}{l}=15) \text { in their engagement with English } \\
\text { language media in the digital wild. } \\
\text { Drawing on ethnographic interviews } \\
\text { (Spradley, 1979), during which the } \\
\text { participants engaged in online English } \\
\text { language activities (e.g., gaming, } \\
\text { snapchatting, etc.) (Jensen, 2019) }\end{array}$ \\
\hline 8 & 2018 & $\begin{array}{l}\text { Online Informal } \\
\text { Language } \\
\text { Learning: Insights } \\
\text { From A } \\
\text { Korean Learning } \\
\text { Community }\end{array}$ & $\begin{array}{l}\text { Daniel } \\
\text { Isbell }\end{array}$ & $\begin{array}{l}\text { To report on a netnographic } \\
\text { investigation (Kozinets, 2010) of an } \\
\text { online community for } \\
\text { learning Korean. }\end{array}$ \\
\hline 9 & 2016 & $\begin{array}{l}\text { Language-As } \\
\text { Victory: A Study of } \\
\text { Gaming Literacy } \\
\text { Practices in } \\
\text { Second-Language } \\
\text { Contexts }\end{array}$ & $\begin{array}{l}\text { Raúl Alberto } \\
\text { Mora, et.al. }\end{array}$ & $\begin{array}{l}\text { To explore how gamers use English as } \\
\text { an influential language practice for } \\
\text { their success in the gaming experience. } \\
\text { (Mora et al., 2016) }\end{array}$ \\
\hline 10 & 2018 & $\begin{array}{l}\text { The Online } \\
\text { Ecology of Literacy } \\
\text { and Language } \\
\text { Practices of a } \\
\text { Gamer }\end{array}$ & $\begin{array}{l}\text { Boris } \\
\text { Vazquez- } \\
\text { Calvo }\end{array}$ & $\begin{array}{l}\text { To explore digital literacy practices } \\
\text { prompted by gaming as a fan practice } \\
\text { and to unearth the literacy and } \\
\text { language learning practices of Selo, an } \\
\text { active gamer who translates games } \\
\text { from English into Spanish for fun and } \\
\text { whose translations prompt online } \\
\text { language discussions with other } \\
\text { gamers in the fandom (an online space } \\
\text { where fans share their activities). } \\
\text { (Vazquez-Calvo, The Online Ecology } \\
\text { og Literacy and Language Practices of } \\
\text { a Gamer, 2018) }\end{array}$ \\
\hline
\end{tabular}

On the next part is about the applied research method, result and discussion, and conclusion based on the articles mentioned as in the following table:

\begin{tabular}{|c|c|c|c|}
\hline No & Method & Result and Discussion & Conclusion \\
\hline 1 & Qualitative: & In the article discusses about how MLP is & Regarding translation \\
\hline & Digital & popular among men and older male fans have & practices, it was noted \\
\hline & Ethnography & been extremely active in producing & that several instances \\
\hline & & multimodal and plurilingual fan practices. & of bronies receiving \\
\hline & & Besides, explore how two different groups of & and mentoring from \\
\hline & & Bronies one in Russia and the other in Spain & fellow fans who have \\
\hline & & carry out fan practices in English. It was also & a higher level of \\
\hline & & $\begin{array}{l}\text { found that there were six different cases } \\
\text { adult MLP fans. They both consume }\end{array}$ & $\begin{array}{l}\text { English and he } \\
\text { process of adapting }\end{array}$ \\
\hline & & create products such as fanfiction, & their written output \\
\hline & & & $\begin{array}{l}\text { for } \\
\text { readerships, }\end{array}$ \\
\hline
\end{tabular}




\begin{tabular}{|c|c|c|c|}
\hline & & technologies. & $\begin{array}{l}\text { can acquire some } \\
\text { important } \\
\text { transcultural skills }\end{array}$ \\
\hline 2 & $\begin{array}{l}\text { Qualitative: } \\
\text { Book } \\
\text { Review in } \\
\text { Digital } \\
\text { Context }\end{array}$ & $\begin{array}{l}\text { Discussing about the book that tells project- } \\
\text { based language learning, technology, learner } \\
\text { collaboration, EFL classroom in Japan. In } \\
\text { addition, it also discusses about TBLT, PBLT, } \\
\text { and CALL as technology-based approaches in } \\
\text { current language classrooms within a socio- } \\
\text { constructivist pedagogy (collaboration, } \\
\text { learner-centredness, motivation, intercultural } \\
\text { skills, community, amongst, others). It also } \\
\text { told about how the research was done in the } \\
\text { framework of ethnographic digital or } \\
\text { technology based. }\end{array}$ & $\begin{array}{l}\text { This article concluded } \\
\text { that how the book is } \\
\text { shared valuable } \\
\text { information about } \\
\text { technology that can } \\
\text { be applied in foreign } \\
\text { language learning } \\
\text { particularly in Japan } \\
\text { context. }\end{array}$ \\
\hline 3 & $\begin{array}{l}\text { Qualitative: } \\
\text { Ethnography } \\
\text { in Digital } \\
\text { Context }\end{array}$ & $\begin{array}{l}\text { The article mainly discusses about } \\
\text { interactivity and multimodality in language } \\
\text { learning and the untapped potential of } \\
\text { audiobooks where the research was done in } \\
\text { Denmark. It also describes about the audio } \\
\text { deliverables application, carbooks } \\
\text { demonstrates the versatility of audio as a } \\
\text { communication modality by mapping } \\
\text { gamebooks into mobile-friendly, interactive } \\
\text { audiobooks, social audiobook, Audook: social } \\
\text { experience of audiobooks. }\end{array}$ & $\begin{array}{l}\text { The research showed } \\
\text { that interactive } \\
\text { audiobooks is better } \\
\text { integrated in English } \\
\text { language learning } \\
\text { context from content } \\
\text { generation to social } \\
\text { and game-like } \\
\text { interactively. }\end{array}$ \\
\hline 4 & $\begin{array}{l}\text { Qualitative: } \\
\text { Ethnography } \\
\text { in Digital } \\
\text { Context }\end{array}$ & $\begin{array}{l}\text { The article discusses about the project of } \\
\text { training given towards } 10 \text { students of } \\
\text { Southampton university that learned on } \\
\text { conducting ethnographic study that involved: } \\
\text { 1) Ethnographic methods training sessions, 2) } \\
\text { Project overview and initial feedback on } \\
\text { ethnographic projects, 3) Doing Ethnography } \\
\text { Q\&A session, 4) Ethnographic methods } \\
\text { session (as part of a taught module), } \\
\text { 4)Participant observation activity and } \\
\text { discussion, 5)Individual discussions of } \\
\text { ethnographic projects, 6) Students advised on } \\
\text { archiving of research materials, 7) Digital } \\
\text { literacy skills assessment and training session, } \\
\text { 8) Students provided with audio recorders and } \\
\text { small video cameras, 9) E-Folio6 } \\
\text { Ethnographic Encounters blog site established } \\
\text { and initial student posts written. }\end{array}$ & $\begin{array}{l}\text { The conclusion of the } \\
\text { research was the } \\
\text { ethnographic training } \\
\text { can provide a starting } \\
\text { point to help students } \\
\text { to open their eyes to } \\
\text { critical engagement } \\
\text { with the place of } \\
\text { encountering. It also } \\
\text { offers potential } \\
\text { for bridging different } \\
\text { academic traditions } \\
\text { and seems } \\
\text { particularly well- } \\
\text { suited for Modern } \\
\text { Languages students. }\end{array}$ \\
\hline 5 & $\begin{array}{l}\text { Qualitative: } \\
\text { Ethnography } \\
2.0 \text { or in } \\
\text { Digital }\end{array}$ & $\begin{array}{l}\text { The article discusses about the extent to } \\
\text { which Poetry Writing } 2.0 \text { can create an } \\
\text { expressive and creative English language } \\
\text { learning environment. Moreover, the article }\end{array}$ & $\begin{array}{l}\text { The findings show } \\
\text { benefits of blended } \\
\text { poetry writing: (1) } \\
\text { build an engaging }\end{array}$ \\
\hline
\end{tabular}




\section{Context}

\section{Qualitative:}

Autoethnography describes the gap between what the students wanted to say and what they could say gave them contextual experience in how to use English grammar to express their feelings and thoughts. They had the opportunity to collaboratively envision the writing of a poem. By looking at the picture, the students gave and wrote their expressive and creative ideas on Facebook. The blended learning group allows the students to engage in a helpful sharing and discussion platform, and eventually, this can empower them to help each other. The blended learning environment also eliminates the students' writing blocks when drafting their poems. Facebook could be seen as a virtual platform for creating or designing creative language pedagogy which allows students to craft their creative work, such as poems. The teacher's final grading report and feedback on students' poems aimed to recognize students' hard work and value the joy of poem writing inasmuch as the students had invested their time, energy, and effort to a poetry writing enterprise.

The article discusses about; firstly, language as a system of structural patterns that the way vocabulary is presented on Busuu does not differ significantly from the way the presentation of grammar operates. Busuu follows the traditional "drill-and-kill" approach in presenting grammatical items, focusing on repetition of isolated sentences and translation that is typical of past teaching methods. Secondly, language as interaction interactions afforded in the Busuu talk area (chat interface) and the section of Busuu groups (forum interface1) brought a sense of balance to the pervasive structural view of language that underlined other spaces of the website. Language as a tree growing in a garden The Language Garden is divided into two panels, each one with a semiotic cluster that recreates several objects (e.g. animals, plants) through animation

7 Qualitative: Findings showed that the young users to a Ethnography large degree seemed driven by social and in Online/ writer and reader community; (2) allow for negotiating topics of poems; (3) picture or photographs as visual artifacts bring poetry writing to life; (4)provide further impetus for peer and teacher scaffolding as dialogic support for students;

Facebook is seen as a social networking site for enacting expressive and creative language instruction; and (6) students prefer having their poems assessed in a humanistic way in order to experience the joy of poem writing.

\section{Results indicate that Busuu is an ecological system composed of nested sub-systems that reflect structural, interactional, and ecological views of language that interweave in conflicting and complementary ways.}

The study shows that
most of the
participants were




\begin{tabular}{|c|c|c|c|}
\hline & $\begin{array}{l}\text { Digital } \\
\text { Context }\end{array}$ & $\begin{array}{l}\text { with English. By token of their great interest } \\
\text { in the activities, the children engaged } \\
\text { extensively with English. Findings showed } \\
\text { that both the content and the mediating } \\
\text { language of the activities were of great } \\
\text { personal significance to the children. AT } \\
\text { emphasizes how language learning is } \\
\text { inherently social in nature, initially taking } \\
\text { place in the social sphere to later become } \\
\text { internalized by the individual. For some, } \\
\text { engagement with English in school was } \\
\text { driven by lower cognitive motives carrying } \\
\text { little personal significance. }\end{array}$ & $\begin{array}{l}\text { motivated in in their } \\
\text { involvement } \\
\text { using English by } \\
\text { social and higher } \\
\text { cognitive motives, } \\
\text { engaged } \\
\text { substantially with } \\
\text { affordances for } \\
\text { language learning, } \\
\text { engaged in chats, and } \\
\text { read and listened to } \\
\text { online content. }\end{array}$ \\
\hline 8 & $\begin{array}{l}\text { Qualitative: } \\
\text { Ethnography } \\
\text { Netnographic }\end{array}$ & $\begin{array}{l}\text { The discussion of the article tells about the } \\
\text { object (in AT terms) of r/Korean community } \\
\text { activity to learn English. However, in } \\
\text { practice, this primarily means learning about } \\
\text { Korean and is most often accomplished via } \\
\text { English as a mediational tool. There were } 13 \\
\text { excerpts discussed in the article as follows: A } \\
\text { Language Knowledge Topic, Writing Practice } \\
\text { about Music, petericn (\{Native Speaker }\} \text {, } \\
\text { OEQ), Geurim (\{Advanced }\} \text {, OEQ), } \\
\text { Participatory Interaction (r/Korean), Tom } 88 \\
\text { (\{Intermediate }\} \text { OEQ)Addressing an } \\
\text { Inaccurate Response (r/Korean), Do not use } \\
\text { Romanization (r/Korean)annyeong_kiwi } \\
\text { (\{Beginner }\} \text {, OEQ) Tom88 (\{Intermediate }\} \text {, } \\
\text { OEQ) petericn (\{Native Speaker }\}, \text { OEQ), } \\
\text { FunCreatures (\{Beginner }\}, \text { OEQ) }\end{array}$ & $\begin{array}{l}\text { In OEQ responses, } \\
\text { r/Korean comments, } \\
\text { and chatroom } \\
\text { discussion, many } \\
\text { r/Korean members } \\
\text { revealed that they } \\
\text { engaged in Korean } \\
\text { learning activity in } \\
\text { numerous spaces, } \\
\text { both online and } \\
\text { offline (e.g., chatting } \\
\text { apps, Skype tutors, } \\
\text { daily life in Korea, } \\
\text { classroom study) }\end{array}$ \\
\hline 9 & $\begin{array}{l}\text { Qualitative: } \\
\text { Blended } \\
\text { Ethnography } \\
\text { and Digital } \\
\text { Ethnography }\end{array}$ & $\begin{array}{l}\text { The discussion started by important fact that } \\
\text { adds to the prevalence of English is language } \\
\text { attrition: Not all games are translated to all } \\
\text { languages, thus encouraging players to } \\
\text { understand at very least the terms used within } \\
\text { their games and emulating them in order to } \\
\text { effectively make themselves understood } \\
\text { during the matches. Next, there is not a } \\
\text { necessity to be a proficient person in English } \\
\text { language, but in order to communicate a } \\
\text { meaningful message, you ought to at least } \\
\text { hinge the theoretical part with the practical } \\
\text { because it is not something that could be } \\
\text { developed per se. Through the interactions } \\
\text { practiced in the game, Tom (the gamer) has } \\
\text { managed to improve his English competence } \\
\text { quite dramatically. }\end{array}$ & $\begin{array}{l}\text { The findings show } \\
\text { how English appears } \\
\text { in gaming } \\
\text { communities as a } \\
\text { need for appropriation } \\
\text { of the language and as } \\
\text { communicative } \\
\text { resource for victory } \\
\text { where every genre } \\
\text { entails very diverse } \\
\text { codes, lingo, and key } \\
\text { phrases without } \\
\text { which failure is a very } \\
\text { realistic option. In } \\
\text { addition, this } \\
\text { presentation outlined } \\
\text { some key issues and } \\
\text { directions or literacy }\end{array}$ \\
\hline
\end{tabular}




\begin{tabular}{|c|c|c|c|}
\hline & & & $\begin{array}{l}\text { research and second } \\
\text { language learning and } \\
\text { teaching. }\end{array}$ \\
\hline 10 & $\begin{array}{l}\text { Qualitative: } \\
\text { Virtual } \\
\text { Ethnography }\end{array}$ & $\begin{array}{l}\text { The article discusses about Ecology of Selo's } \\
\text { fandom those are fans as players, fans as } \\
\text { readers, fans as commenters, otherwise the } \\
\text { issues were (1) Selo's literacies and fan } \\
\text { translation process as the main generator, and } \\
\text { (2) as a by-product of Selo's translations, the } \\
\text { forum comments and how they serve for } \\
\text { informal language learning. Selo's literacies } \\
\text { within the stages were (1) decoding the texts, } \\
\text { (2) translating the texts, (3) testing the games, } \\
\text { (4) creating a patch with the translation, (5) } \\
\text { publishing the patch, (6) advertising the } \\
\text { translations, and (7) curating and managing } \\
\text { the network of fans who use the translations. } \\
\text { Fans' comments were covering } 4 \text { main } \\
\text { themes: (1) functions of translated games, (2) } \\
\text { translation and language, (3) socialization, } \\
\text { and (4) conflicts. }\end{array}$ & $\begin{array}{l}\text { Results show that (1) } \\
\text { Selo's fandom is a } \\
\text { complex semiotic } \\
\text { social space (2) Selo } \\
\text { has a sophisticated set } \\
\text { of literacy skills ( } 3 \text { ) } \\
\text { Selo and other fans } \\
\text { learn language items } \\
\text { located and } \\
\text { meaningful in the } \\
\text { authentic conditions } \\
\text { of textual production. }\end{array}$ \\
\hline
\end{tabular}

Even though there were many researchers particularly in language area within digital surrounding such as (Bajrami \& Ismaili, 2016; Beschorner et al., 2018; Cuaca Dharma et al., 2017; Jozwik \& Mustian, 2019; Sirivedin et al., 2018; Tridinanti, 2017), yet, in the fact that the research of DE in language learning field is still rarely done or found by researchers, probably it basically comes from anthropology or sociology that poses culture value in the research analysis. Therefore, the discussion above limits only in the number of 10 articles that were chosen particularly in language learning studies.

Beginning from a discussion of the first article that the research focus is on fans community of MLP that comes from Russia and Spanish involving their watching or fandom withing language learning and it can increase their English skills such as consume and create products such as fanfiction, translations, and fandubbing in different contexts with the use of sophisticated technologies (Shafirova \& Cassany, 2019), firstly, this study was done in digital ethnography where the data taken new literacies spawned by the Internet and new technologies interconnected with social practices and meanings. Even though the participants were in limited number and also the research done in limited time, it cannot be denied that this kind of research is something new that how the fanfiction could be as an inspiration to do a digital ethnography research.

Secondly, the interesting article was about book review research that gave brief exploration of an outstanding book entitled "Project-Based Language Learning with Technology: Learner Collaboration in An EFL Classroom in Japan" that was written by Michael Thomas (Moreira, 2019). The book was reviewed sophistically in how English language learning was blended and implemented with the technology in the setting of Japan. It was also explained sequentially per chapters and described in chic and nice words that make the readers persuasively interested to read its book. However, what it must be underlined here as the focus on this literature research that focus on DE, this one is related on what the book contains that discusses about blended approach, method, or even procedures in EFL context with technology such as PBLT, TBLT, and CALL that the research about them can be done through DE. Even, the setting of the book is in Japan, yet it can be 
adapted in surrounding Asia region as the implication of that book.

Thirdly, the article displayed the study of interactive audiobooks for primary and secondary students in improving their English language learning particularly in Denmark (Marchetti \& Valente, 2018). The discussion in the articles mainly talk about two supporting case studies, audio deliverables, carbooks, the main case study: social audiobooks, audook: social experience of audiobooks. They also found that the interactive audiobooks beside can improve their language skill but also add their social experience semiotically. Not only that, it is also exploring how the transduction of literary texts could foster different experiences when it moving from the visual and tangible modes associated to the experience of physical books and e-readers to the auditory modality enhanced by interactivity. The idea of this article is awesome because the research of interactive audiobooks can inspire other researchers to improve literacy field by innovative digital tool that can be useful for English language learning context. Nonetheless, the setting is only in Denmark and the participants are only from primary and secondary school, yet their invention is interesting to be followed in other setting contexts. In addition, the digital ethnography method is really deep and detail that it spent two years of the research duration.

Fourthly, the article demonstrated toward students that joined the modern language or innovative pedagogic project or by giving training that focused on learning of ethnography in modern context where the digital aids were used for instance, website and blog to place their result works of training (Demossier et al., 2019). Nevertheless, only 10 students who persistently joined in that project on the setting in Southampton University, yet it can be a new idea that it gives multiples benefit. And, the research method used was systematically and procedurally displayed in its study.

Fifthly, the article that the topic is Poetry Writing 2.0 (Widodo et al., 2016) he described his research in ethnography 2.0 where the learning media used that can be useful of learning poetry which could be fun is Facebook. He also found some requirements that there were six items in teaching poetry that it could be more accepted by the students when they learn and writing poetry. He showed from his article that the teaching of literary work that one is poetry must closeness or familiarity to the students as the writer and let them immerge their sense of imagination by aided with Facebook or some pictures that could be as an inspiration to write. He displayed the research method of ethnography 2.0 with complete research context and fine research design that can be as the example on further similar research.

Sixthly, the displayed article was focused on the implementation of application namely Busuu that in its research was observed an autoethnography on English language learning (Álvarez Valencia, 2016). She found that because in Busuu she teaches language in audio visually and the systematically as such a kind of drilling procedure that she agreed with the theory of audiolingual method where repetition of lexical items or grammar forms on many occasions without any communicative purpose characterizes a great proportion of learning activities at all levels (A1, A2, $\mathrm{B} 1$, and B2) within the aim is as a control practice on learning grammar and vocabulary. She also defined that Busuu may as a social interaction between Busuu users in several levels that can have chat in three kinds of semiotics clusters picture, the roles, and communication facilities. She analogized Busuu as a language as a tree growing in a garden. It is such a metaphor to describe Busuu that provides a holistic, dynamic and interactive, and situated space in which the linguistic repertoires (L1, L2) of learners become one more source of language development. Although she displayed in Busuu on website and explored in in limited sample user that was taken from website, her research result may give implication on pursuing English language practice that this application may be used in classroom as an alternation of blended learning. In addition, it may give an idea to study in the same line that one is autoethnography in other applications or instruction technologies in ELT.

Seventhly, it is about the article that discusses English language learning with digital media 
in outside school by young perspectives (Jensen, 2019) where he concentrated on (7-11) Danish children who surfed online in learning English from the internet. His result that the young participants mostly with high engagement cognitive motive on learning English were motivated using digital media and he also paid attention on low engagement cognitive motive where the young participants were not interested in learning English because what was presented in the digital media is on English not in Danish. Even though in the article, it wasn't explained the duration of research taken, but it was designed by interviewing the participants in regular way without any tendencies form the researcher a he quoted from Spradley model as one of the authentic of ethnography research that sometimes it was a challenge to observe in young participants perspective. And, this kind of research may invite other researcher in the similar idea.

Eighthly, on this article was interesting that the research design used netnographic that it is an extended from ethnography study but more focused on data analysis as (Isbell, 2018) Even though, he conducted his research approximately only 7 weeks on an online community for learning Korean that on his findings revealed relatively little target-language use and a great deal of learning about language. English was used $93 \%$ of the time on the forum, and $81 \%$ of the time in the chatroom. In addition, on his findings include highly-participatory interactional patterns for learning about linguistic forms, community rules designed to promote learning on a democratically organized web platform, and a stark division of community labour between language learners and language experts. He treated the data in this study as observations of a community rather than texts within the total of 55 codes emerged across data sources. Nonetheless, his research was in short period, yet he tried to complete his research design to find quality of finding by doing asynchronous and synchronously, field noting, and open-ended questionnaires. One of the reasons, it may he didn't do an interview on the participants was focusing on digital data analysis, even though actually also it could be held in online way. However, his genuine idea about thematic culture target from netnographic may invite other researchers to use this method as something new to be tried.

Ninthly, the article was presented by starting the statement on the powerful of ability in English language that may determine the victory on game match (Mora et al., 2016). As the focus on this literature study digital ethnography in this article systematically quite good as was taken for two years of observation, this research times was supposedly bringing the fine findings. Unfortunately, with the length of duration, the research findings do not seem strong appearing the thematic cultures as the authentic in ethnographic study, it just displayed at glancing where the gamers immersed by English learning strategies while they were paying game. Therefore, the parts on culture categorizations were unclearly shown up. In addition, the findings of interviews were also unpresented, only the emergences of several words or phrases that showed the part of immersions from English language learning. And, regard to the title that language as the power of victory also seems only as persuasive or attractive invitation to read the article only. However, this article can contribute a such a good idea to apply DE method that nowadays game field is began to be chosen as one of the research topics.

Finally, it comes to the last article discussed in this study that similar with the previous field that is on game research field. The difference on this article compared to (Mora et al., 2016) that studied on how language may as a bridge to win a game for the participants (Sebastián, Tyrone, Michael, and Daniel) and their methods used were both autoethnographic and ethnographic within by doing fieldnotes, taking screenshots of gaming exchanges, and interviews, while (VazquezCalvo, 2018) he focused on the process of translation from Spanish to English by the participant namely "Selo" who conducted a translation from game repertoires and shared to gamer communities that the virtual ethnography research design was proposed by taking from interviews, online observation and screencast videos of the one subject is "Selo" who is a young gamer, whose active life online and literacy repertoire where he spends large amounts of his spare time playing 
games and uses a desktop computer and some emulation software to play console-based games. In the interview was displayed several topics they are: 1) digital profile, 2) digital identity, 3) gaming, 4) conflicts, and 5) fan culture. And, the online observation the author divided into two objectives they are: 1) to describe the online spaces where gamers and fans meet, and 2) to explore the most relevant literacy practices. Screencast video also was used as Selo where he placed the result of his translation and uploaded it on Romhacking.net that was available for gamer community. Besides, email was also used to confirm issues that unclear in the video or others. Finally, corpus data was used too as composing way of the data. The article author classified the data by descriptive and inductive codification of according to the nature: Selo's perceptions and opinions, presentation of translations on online forums, discussion on translation and/or language, other communication among members of the fandom. In addition, he coded the data under the constituent parts of a literacy practice. He triangulated multiple sources of data, covering practices (videos, observation) and perceptions (interview, emails). The result study shows that Selo was a complex semiotic social space, sophisticated set of literacy skills, and situated, meaningful language items under authentic conditions of textual production. Within complete steps of the research design of virtual ethnography, this article can be as a guidance for the next researcher on doing the same method.

\section{CONCLUSION}

Exploring the colourful of DE in various of articles field such as fans community, collaborative aid, interactive audiobooks in outside school context, literary work: writing poetry, social networking: Busuu, digital media in young user perspective, online informal language learning, language used in gaming, and online ecology of literacy give contribution on variative ideas on conducting research using DE design. Moreover, not only presenting the optional topics that can be tried because different setting may result the findings that are not similar, but also the steps of DE that traditionally comes from ethnography and what is the distinct of it. One thing that can be underlined is the keyword of the DE way on collecting data is applied in digitally or virtually (Hjorth, 2017; Horst, 2017; Pink, 2016; Russo, 2017). The contribution of this study implies towards the researchers who are interested on DE where today it is one of the update topics that is needed to investigate more. As the limitation of this study that focuses on DE in applied language learning and the small numbers of the articles revealed, it can invite the further research more specifically in one of kind of the languages or the bigger number of related articles that to be explored.

\section{REFERENCES}

Álvarez Valencia, J. A. (2016). Language views on social networking sites for language learning: the case of Busuu. Computer Assisted Language Learning, 29(5), 853-867. https://doi.org/10.1080/09588221.2015.1069361

Bajrami, L., \& Ismaili, M. (2016). The Role of Video Materials in EFL Classrooms. Procedia Social and Behavioral Sciences, 232(April), 502-506. https://doi.org/10.1016/j.sbspro.2016.10.068

Bandan, A. P., \& Dewanti, R. (2019). Designing ICT Competences-Integrated Syllabuses of Speaking Courses (Design and Development Study of English Language Education Program Syllabuses). International Journal of Language Education and Cultural Review (IJLECR) eJurnal, 5(2), 1-13. https://doi.org/doi.org/10.21009/IJLECR.052.11

Beschorner, B., Colwell, J., Hutchison, A., \& Woodward, L. (2018). Using the technology integration planning cycle to prepare pre-service teachers for multimodal instruction. Literacy Research, Practice and Evaluation, 9, 13-27. https://doi.org/10.1108/S2048045820180000009002 
Chelmsky, E. (1989). Content Analysis: A Methodology for Structuring and Analyzing Written Material.

Creswell, J. W. (2012). Educational Research Planning, Conducting and Evaluating Quantitative and Qualitative Research. Pearson Education Ltd.

Cuaca Dharma, H. R., Asmarani, D., \& Dewi, U. P. (2017). Basic Japanese Grammar and Conversation e-learning through Skype and Zoom Online Application. Procedia Computer Science, 116, 267-273. https://doi.org/10.1016/j.procs.2017.10.055

Demossier, M., Bernasek, L., \& Armbruster, H. (2019). Teaching ethnography as Modern Languages method: legacies and future practices for global citizens. Language, Culture and Curriculum, 32(3), 285-298. https://doi.org/10.1080/07908318.2019.1661685

Elo, S., \& Kyngas, H. (2007). The Qualitative Content Analysis Process.

Hjorth, L. et . a. (2017). The Routledge Companion to Digital Ethnography. Routledge.

Horst, H. (2017). Digital Ethnography. Springer International Publishing.

Hudha, A.M., Dyah, W.E., \& Husamah. (2014). Character Education Model in Mathematics and Natural Sciences Learning at Muhammadiyah Junior High School. International Journal of Education, Learning \& Development Vol. 2 No. 4 , 33-47.

Isbell, D. R. (2018). Online informal language learning: Insights from a Korean learning community. Language Learning and Technology, 22(3), 82-102.

J. Taylor, S., Bogdan, R., \& DeVault, M. 1. (2016). Introduction to Qualitative Research Methods. John Wiley \& Sons, Inc.

Jensen, S. H. (2019). Language learning in the wild: A young user perspective. Language Learning and Technology, 23(1), 72-86. https://doi.org/10.125/44673

Jozwik, S., \& Mustian, A. L. (2019). Effects of Technology-Supported Language Experience Approach for English Learners With Exceptional Needs. Reading and Writing Quarterly, 0(0), 1-19. https://doi.org/10.1080/10573569.2019.1655690

Krippendorff, K. (2004). Content Analysis: An Introduction to Its Methodology.

L.R. Gay, G. E. M. P. A. (2012). Educational research : competencies for analysis and applications (10th Ed.). Pearson Education, Inc.

Leavy, P. (2017). Research Design Quantitative, Qualitative, Mixed Methods, Arts-Based, and Community-Based Participatory Research Approaches. The Guilford Press.

Marchetti, E., \& Valente, A. (2018). Interactivity and multimodality in language learning: the untapped potential of audiobooks. Universal Access in the Information Society, 17(2), 257274. https://doi.org/10.1007/s10209-017-0549-5

Mora, R. A., Castaño, S., Orrego, T. S., Hernandez, M., \& Ramírez, D. (2016). Language-AsVictory: a Study of Gaming Literacy Practices in Second-Language Contexts. INTED2016 Proceedings, 1(January 2019), 2823-2831. https://doi.org/10.21125/inted.2016.0163

Moreira, M. A. (2019). Project-based language learning with technology: learner collaboration in an EFL classroom in Japan. Innovation in Language Learning and Teaching, 1229, 1-3. https://doi.org/10.1080/17501229.2019.1591419

Mosadeghi, S., Keller, M. S., Cohen, E. R., Martinez, B. M., Kwan, J. T., \& Spiegel, B. (2016). Tu1912 Using Digital Ethnography. Gastroenterology, 150(4), $\quad$ S975. https://doi.org/10.1016/s0016-5085(16)33305-4

Muranova, O. (2016). New Media and Perennial Problems in Foreign Language Learning and Teaching. In CALICO Journal (Vol. 34, Issue 3). https://doi.org/10.1558/cj.32173

Næss, H. E. (2017). Authenticity matters: A digital ethnography of FIA World Rally Championship fan forums. Sport Management Review, 20(1), 105-113. https://doi.org/10.1016/j.smr.2016.08.001 
Pink, S. et. a. (2016). Digital Ethnography Principles and Practice. Sage.

Purnawati, \& Iskandar, I. (2019). Designing ICT Competences-Integrated Syllabuses of Grammar Courses for English Language Education Study. International Journal of Language Education and Cultural Review (IJLECR), 5(2), 104-115. https://doi.org/doi.org/10.21009/IJLECR.052.12

Russo, V. (2017). Digital Ethnography Theories, Models, and Case Studies. MathematicalStatistical Models and Qualitative Theories for Economic and Social Sciences, Studies in Systems, Decision and Control 104, 41-53. https://doi.org/10.1007/978-3-319-54819-7

Shafirova, L., \& Cassany, D. (2019). Bronies learning English in the digital wild. Language Learning and Technology, 23(1), 127-144. https://doi.org/10.125/44676

Sirivedin, P., Soopunyo, W., Srisuantang, S., \& Wongsothorn, A. (2018). Effects of Facebook usage on English learning behavior of Thai English teachers. Kasetsart Journal of Social Sciences, 39(2), 183-189. https://doi.org/10.1016/j.kjss.2018.03.007

Syifa, S., \& Darmahusni. (2019). Designing ICT Competences-Integrated Syllabuses of Research Skills and Professional Administration Courses (Design and Development Study of English Language Education Study Program Syllabuses). International Journal of Language Education and Cultural Review (IJLECR), 5(2), 116-123. https://doi.org/DOI: doi.org/10.21009/IJLECR.052.14

Tampubolon, T., \& Darmahusni. (2019). Designing ICT Competences-Integrated Language Awareness (English Phonetics and Phonology, English Morphology and Syntax, And English Sociopragmatic) Assessment Instruments for ELESP. International Journal of Language Education and Cultural Review (IJLECR), 5(2), 124-130. https://doi.org/DOI: doi.org/10.21009/IJLECR.052.14

Thompson, A., Stringfellow, L., Maclean, M., \& Nazzal, A. (2020). Ethical considerations and challenges for using digital ethnography to research vulnerable populations. Journal of Business Research, February, 0-1. https://doi.org/10.1016/j.jbusres.2020.02.025

Tridinanti, G. (2017). English Introduction Through Digital Storytelling in Early Childhood. International Journal of Language Education and Culture Review, 3(1), 49-55. https://doi.org/doi.org/10.21009/IJLECR.031.06

Vazquez-Calvo, B. (2018 ). The Online Ecology of Literacy and Language Practices of a Gamer. Educational Technology \& Society, 21(3), 199-212.

White, R., \& Warfa, N. (2011). Building Schools of Character - A Case-study Investigation of Character Education's Impact on School Climate, Pupil Behavior, and Curriculum Delivery. Journal of Applied Social Psychology Vol.4 No.1 , 1-15.

Widodo, H. P., Budi, A. B., \& Wijayanti, F. (2016). Poetry writing 2.0: Learning to write creatively in a blended language learning environment. Electronic Journal of Foreign Language Teaching, 13(1), 30-48.

Zhang, Y., \& Wildemuth, B. Qualitative Analysis of Content. 